\title{
Faktor-Faktor yang Mempengaruhi Return Saham Syariah Perusahaan Sub Sektor Tourism, Restaurant, and Hotel
}

\section{Factors affecting the return sharia stock of tourism, restaurant, and hotel sub sector companies}

\section{Harivani Nurwiyati}

Program Studi D4 Keuangan Syariah, Politeknik Negeri Bandung

E-mail: harivani.nurwiyati.ksy16@polban.ac.id

\section{Diharpi Herli Setyowati}

Jurusan Akuntansi, Politeknik Negeri Bandung

E-mail: diharpi@yahoo.co.id

\section{Destian Arshad Darulmalshah Tamara}

Jurusan Akuntansi, Politeknik Negeri Bandung

E-mail: destian.arshad@polban.ac.id

\begin{abstract}
The purpose of this study is to analyze the influence of current ratio, debt to equity ratio, return on equity, and inflation rate to return stock of sub sector tourism, restaurant, and hotel companies listed on Indonesia Sharia Stock. Index (ISSI). The population used is sharia service sector companies listed on ISSI. The sample is determined using purposive sampling. This research is a descriptive study with a quantitative approach. The data analysis method used is a panel data regression. Based on the results with a significance level of 5\%, this study shows: Current ratio, Debt to equity ratio, and Inflation rate partially have No. significant effect to return stock. Return on equity partially has asignificant negative effect to return stock. Current ratio, debt to equity ratio, return on equity, inflation rate simultaneously have a significant effect on stock returns.
\end{abstract}

Keywords: return stock, Indonesia Sharia Stock Indeks, regression

\section{Pendahuluan}

Saham syariah dikelompokan menjadi 9 sektor perusahaan. Pengelompokkan tersebut untuk memudahkan pasar dalam mengidentifikasi kinerja perusahaan sesuai dengan kelompok usahanya. Memperhatikan laporan Global Islamic Economy Indicator (GIEI), pariwisata halal Indonesia mengalami peningkatan nilai dari tahun ke tahun. Hal tersebut menunjukkan potensi yang baik sebagai salah satu sektor pilihan berinvestasi. Pasar modal syariah mengelompokan sektor pariwisata ke sektor trade, service, and investment sub sektor tourism, restaurant, and hotel. Meskipun sektor pariwisata termasuk sektor niche yang ditargetkan memiliki perkembangan yang bagus, saham syariah sub sekor tourism, restaurant, and hotel tidak termasuk ke dalam Jakarta Islamic Index (JII), yaitu indeks saham syariah yang memuat 30 dari 70 perusahaan saham syariah yang memiliki kinerja perusahaan dan likuiditas yang tinggi.

Investor yang sangat pintar, pertama kali kriteria yang digunakan untuk membeli saham yaitu likuiditas saham dan kriteria kedua adalah faktor fundamental yang ditunjukkan melalui rasio keuangan dan kejadian yang secara langsung maupun tidak langsung mempengaruhi kinerja keuangan (Manurung, 2009). Melalui penilaian kinerja keuangan, pencapaian perusahaan dapat ikut 
terukur (Farihah \& Setiawan, 2020). Hal yang harus diperhatikan tersebut untuk meminimalisir peluang terjadinya kerugian, karena investor berusaha memperoleh keuntungan optimal atas investasi yang dilakukannya. Setiap perusahaan sub sektor tourism, restaurant, and hotel pernah mengalami return saham negatif dan tidak memberikan return saham yang konsisten tinggi. Setiap tahun dari tahun 2012 sampai 2018 terdapat perusahaan yang mengalami penurunan return saham, sehingga perlu memperhatikan kinerja keuangan yang dilihat dari rasio keuangan untuk melihat pengaruhnya terhadap return saham.

Tabel 1 Data Return saham, Current Ratio, Debt to Equity Ratio,dan Return on Equity

\begin{tabular}{cccccccccc}
\hline \multirow{2}{*}{ No } & \multirow{2}{*}{ Emiten } & \multicolumn{2}{c}{ Return } & \multicolumn{2}{c}{ CR } & \multicolumn{2}{c}{ DER } & \multicolumn{2}{c}{ ROE } \\
\cline { 3 - 10 } & $\mathbf{2 0 1 4}$ & $\mathbf{2 0 1 5}$ & $\mathbf{2 0 1 4}$ & $\mathbf{2 0 1 5}$ & $\mathbf{2 0 1 4}$ & $\mathbf{2 0 1 5}$ & $\mathbf{2 0 1 4}$ & $\mathbf{2 0 1 5}$ \\
\hline $\mathbf{1}$ & ARTA & 0.6244 & 0.1441 & $443.09 \%$ & $744.94 \%$ & 0.1993 & 0.1990 & $3.7 \%$ & $0.5 \%$ \\
\hline $\mathbf{2}$ & BAYU & 1.4875 & 0.2563 & $154.42 \%$ & $160.13 \%$ & 0.89 & 0.72 & $13.6 \%$ & $7.0 \%$ \\
\hline $\mathbf{3}$ & FAST & 0.1053 & -0.4524 & $188.25 \%$ & $126.19 \%$ & 1.06 & 1.07 & $14.8 \%$ & $9.4 \%$ \\
\hline $\mathbf{4}$ & ICON & 0.2444 & 0.3504 & $198.95 \%$ & $146.93 \%$ & 0.81 & 1.71 & $3.5 \%$ & $3.9 \%$ \\
\hline $\mathbf{5}$ & INPP & -0.0286 & 0.7549 & $196.53 \%$ & $141.41 \%$ & 0.77 & 0.24 & $4.9 \%$ & $2.8 \%$ \\
\hline $\mathbf{6}$ & JIHD & -0.2105 & -0.4429 & $199.07 \%$ & $109.52 \%$ & 0.39 & 0.45 & $2.9 \%$ & $2.1 \%$ \\
\hline $\mathbf{7}$ & JSPT & 0.0000 & 0.2467 & $236.36 \%$ & $281.97 \%$ & 0.55 & 0.49 & $13.7 \%$ & $8.5 \%$ \\
\hline $\mathbf{8}$ & KPIG & -0.0153 & 0.0930 & $165.95 \%$ & $111.55 \%$ & 1.11 & 1.33 & $5.2 \%$ & $-2.5 \%$ \\
\hline $\mathbf{9}$ & MAMI & 0.0000 & 0.5800 & $93.74 \%$ & $96.48 \%$ & 0.28 & 0.33 & $0.6 \%$ & $0.4 \%$ \\
\hline $\mathbf{1 0}$ & PJAA & 0.6284 & 0.1408 & $89.55 \%$ & $117.97 \%$ & 0.84 & 0.79 & $15.4 \%$ & $17.2 \%$ \\
\hline $\mathbf{1 1}$ & PNSE & -0.0603 & -0.2495 & $285.15 \%$ & $167.73 \%$ & 0.50 & 0.53 & $10.3 \%$ & $5.6 \%$ \\
\hline $\mathbf{1 2}$ & PTSP & 0.4250 & 0.4912 & $148.90 \%$ & $100.05 \%$ & 0.82 & 1.15 & $13.3 \%$ & $-1.2 \%$ \\
\hline $\mathbf{1 3}$ & PUDP & -0.0813 & -0.0476 & $200.93 \%$ & $164.13 \%$ & 0.39 & 0.44 & $5.2 \%$ & $8.9 \%$ \\
\hline $\mathbf{1 4}$ & SHID & -0.0836 & 0.7752 & $122.44 \%$ & $115.74 \%$ & 0.52 & 0.55 & $1.3 \%$ & $0.0 \%$ \\
\hline
\end{tabular}

Tabel 1 menunjukkan ringkasan data return saham, current ratio, debt to equiy ratio, dan return on equity perusahaan sub sektor tourism, restaurant, and hotel periode 2014-2015. Dari tabel tersebut terlihat bahwa current ratio cenderung menurun, sedangkan return saham cenderung meningkat. Perusahaan yang memiliki rasio likuiditas tinggi diminati para investor dan berimbas pada harga saham yang cenderung akan naik karena tingginya permintaan(Hayati, 2017), semakin tinggi current ratio semakin tinggi return saham. Current ratio yang tinggi menunjukkan jaminan yang lebih baik atas utang jangka pendek, tetapi ketika current ratio terlalu tinggi efeknya terhadap earning power kurang baik karena tidak semua modal kerja dapat didaya gunakan(Amrin, 2009). Investor lebih tertarik pada hasil pengelolaan perusahaan dan bukan pada cara pengelolaannya(Samsul, 2006). Ketika earning menurun, maka terjadi penurunan return saham. Menurut penelitian Bintara dan Tanjung (2019) current ratio berpengaruh positif terhadap return saham. Menurut penelitian Choirurodin (2018) current ratio berpengaruh negatif terhadap return saham. Current ratio dapat berpengaruh positif atau negatif terhadap return saham, namun menurut hasil penelitian Tumonggor (2017), Current Ratio tidak berpengaruh terhadap return saham.

Tabel 1 juga menunjukkan kecenderungan debt to equity ratio yang meningkat. Pada tahun yang sama, return saham cenderung menurun. Investor melakukan investasi pada perusahaan yang sehat. Jika modal sendiri lebih besar daripada modal pinjaman, maka perusahaan dikatakan sehat dan tidak mudah bangkrut, jadi investor mengikuti perkembangan rasio utang terhadap ekuitas atau debt to equity ratio (Samsul, 2006). Semakin tinggi DER menunjukkan ketergantungan perusahaan terhadap modal asing yang menimbulkan pengurangan keuntungan yang diperuntukan untuk membayar margin atau bagi hasil sehingga investor menghindari investasi pada perusahaan dengan DER yang tinggi. DER berpengaruh negatif terhadap return saham, didukung penelitian Bintara dan Tanjung (2019), tetapi berdasarkan penelitian 
Sugiarti (2015), Mayfi dan Rianto (2018) debt to equity ratio tidak berpengaruh signifikan terhadap return saham.

Tahun 2014 ke tahun 2015, return on equity cenderung menurun, pada saat yang sama, return saham cenderung menurun. Investor ingin mengetahui efisiensi manajemen dalam mengelola modalnya melalui rasio return on equity (Samsul, 2006). ROE yang semakin tinggi dan konsisten menggambarkan investasi bertumbuh mengarahkan ke harga saham yang semakin tinggi di masa depan (Fahmi, 2012). Teori tersebut didukung penelitian Abdulmanan dan Faturohman (2015) yang menyatakan bahwa ROE berpengaruh positif terhadap return saham. ROE yang tinggi dapat meningkatkan return saham, namun berdasarkan hasil penelitian Tumonggor (2017) dan Sugiarti (2015) ROE tidak berpengaruh signifikan terhadap return saham.

Tingkat inflasi Indonesia pada tahun 2012, 2013 dan 2014 sebesar 8,86; 8,38 dan 8,36 kemudian pada tahun 2015 sampai dengan 2018 tingkat inflasi Indonesia sebesar 3,35; 3,02; 3,61; dan 3,13. Ketika tingkat inflasi sangat rendah, berarti pertumbuhan perekonomian sedang lamban, pergerakan harga saham pun lamban, tetapi inflasi yang terlalu tinggi dapat mengakibatkan perusahaan-perusahaan bangkrut (Samsul, 2006), sehingga inflasi yang tinggi mengakibatkan return saham menurun. Teori tersebut didukung hasil penelitian Geriadi dan Wiksuana (2017) serta Kurniasari, dkk (2018) yang menyatakan inflasi memiliki pengaruh negatif dan signifikan terhadap return saham, namun hasil penelitian Hidayati dan Topowijono (2018) menunjukkan inflasi tidak berpengaruh signifikan terhadap return saham.

Berdasarkan latar belakang yang telah diuraikan, penelitian sebelumnya menunjukan adanya inkonsistensi hasil, serta dari data yang disajikan pada tabel 1 menunjukan adanya ketidaksesuaian dengan teori yang ada. Oleh karena itu, menarik untuk dilakukan penelitian dengan judul "Faktor-faktor yang mempengaruhi return saham syariah perusahaan sub sektor tourism, restaurant, and hotel."

\section{Kajian Pustaka}

\subsection{Penelitian Terdahulu}

Penelitian sebelumnya telah membahas faktor-faktor internal dan eksternal perusahaan yang diduga mempengaruhi return saham. Penelitian sebelumnya mengambil sampel yang diteliti dari berbagai sektor/ sub sektor/ indeks yang berbeda. Penulis akan melakukan penelitian yang serupa dengan sampel perusahaan sub sektor tourism, restaurant, and hotel. Penelitian sebelumnya telah meneliti berbagai faktor fundamental perusahaan seperti rasio-rasio keuangan dan kebijakan manajemen serta faktor fundamental ekonomi seperti tingkat inflasi, pendapatan domestik bruto, dan kurs mata uang yang mempengaruhi return saham. Penelitian yang akan dilakukan oleh penulis hanya terbatas pada 3 rasio keuangan, yaitu current ratio, debt to equity ratio, dan return on equity sebagai faktor internal perusahaan yang diduga mempengaruhi return saham dan tingkat inflasi sebagai faktor eksternal perusahaan yang diduga mempengaruhi return saham.

Beberapa penelitian terdahulu yang sejenis dengan penelitian yang akan dilakukan adalah sebagai berikut: 
Tabel. 2 Penelitian Terdahulu

\begin{tabular}{|c|c|c|c|c|}
\hline No & $\begin{array}{c}\text { Judul Penelitian dan } \\
\text { Penelitian }\end{array}$ & Metode & ariabel & Hasil Penelitian \\
\hline 1 & $\begin{array}{l}\text { Pengaruh Kinerja } \\
\text { Perusahaan terhadap Retum } \\
\text { Saham (Studi pada } \\
\text { Perusahaan Manufaktur } \\
\text { yang Terdaftar di Bursa } \\
\text { Efek Indonesia) } \\
\text { Sugiarti (2015) }\end{array}$ & $\begin{array}{l}\text { Regresi } \\
\text { Ordinary } \\
\text { least square }\end{array}$ & $\begin{array}{l}\text { Current Ratio, Debt } \\
\text { to Equity Ratio, } \\
\text { Return on Equity, } \\
\text { Earning Per Share }\end{array}$ & $\begin{array}{l}\text { Current ratio berpengaruh negatif } \\
\text { signifikan terhadap return saham. Debt to } \\
\text { equity ratio, Returm on equity, Earning per } \\
\text { share masing-masing tidak berpengaruh } \\
\text { terhadap return saham. }\end{array}$ \\
\hline 2 & $\begin{array}{l}\text { Pengaruh Inflasi, BI Rate } \\
\text { dan Nilai Tukar Terhadap } \\
\text { Return Saham (Studi pada } \\
\text { perusahaan subsector food \& } \\
\text { beverages yang terdaftar di } \\
\text { Bursa Efek Indonesia } \\
\text { periode 2013-2016) } \\
\text { Hidaya Tri Afiyati; } \\
\text { Topowijoyo (2018) }\end{array}$ & $\begin{array}{l}\text { Regresi } \\
\text { Linier } \\
\text { Berganda }\end{array}$ & $\begin{array}{l}\text { Inflasi, BI Rate, dan } \\
\text { nilai tukar }\end{array}$ & $\begin{array}{l}\text { Inflasi, BI Rate, dan nilai tukar secara } \\
\text { simultan berpengaruh terhadap return } \\
\text { saham. Inflasi dan BI-Rate masing- } \\
\text { masing tidak berpengaruh terhadap } \\
\text { returm saham. Nilai tukar berpengaruh } \\
\text { terhadap returm saham. }\end{array}$ \\
\hline . & $\begin{array}{l}\text { The Relationship Between } \\
\text { Fundamental Factors and Stock } \\
\text { Returm: A Case Based } \\
\text { Approach on Banking } \\
\text { Companies Listed in Indonesia } \\
\text { Stock Exchange } \\
\text { Adamilyara Aqil } \\
\text { Abdulmannan; Taufik } \\
\text { Faturohman (2015) }\end{array}$ & $\begin{array}{l}\text { Regresi } \\
\text { Data Panel }\end{array}$ & $\begin{array}{l}\text { Earwing per Share } \\
\text { (EPS), Dividend per } \\
\text { Share (DPS), Fixed } \\
\text { Asset to Total Asset } \\
\text { (FA/TA), Return on } \\
\text { Asset (ROA), Returm } \\
\text { on Equity (ROE) }\end{array}$ & $\begin{array}{l}\text { EPS, DPS, FA/TA, ROA, ROE secara } \\
\text { simultan tidak berhubungan signifikan } \\
\text { terhadap return saham. } \\
\text { DPS, FA/TA, ROE secara parsial } \\
\text { berhubungan positif terhadap return } \\
\text { saham. } \\
\text { EPS dan ROA secara parsial } \\
\text { berhubungan negarif terhadap return } \\
\text { saham. }\end{array}$ \\
\hline
\end{tabular}

\subsection{Current Ratio terhadap Return Saham}

Current Ratio merupakan rasio keuangan yang menggambarkan likuiditas perusahaan. Current Ratio adalah rasio yang menunjukkan kemampuan perusahaan membayar hutanghutang jangka pendek dengan menggunakan aset lancarnya, dalam buku Fahmi (2012) dirumuskan sebagai berikut:

$$
\text { Current Ratio }=\frac{\text { Aktiva lancar }}{\text { Utang lancar }} \times 100 \%
$$

Perusahaan yang memiliki nilai current ratio yang rendah dianggap terjadi masalah likuiditas. Sebaliknya, perusahaan yang memiliki current ratio yang tinggi juga dianggap kurang bagus. Current ratio yang terlalu tinggi menggambarkan terlalu banyak aset lancar yang menganggur yang akhirnya laba perusahaan tidak diperoleh secara maksimal atas penggunaan aset yang tersedia. Rasio ideal current ratio ditentukan dengan mempertimbangkan faktor seperti jenis industri dan kebiasaan kredit.

Current ratio yang rendah menunjukkan masalah likuiditas, tetapi ketika terlalu besar 
menunjukkan banyaknya dana menganggur, sehingga mengurangi kemampuan perusahaan memperoleh laba (Sawir, 2009). Hal tersebut didukung hasil penelitian Sugiarti (2015) menyatakan bahwa current ratio berpengaruh negatif signifikan terhadap return saham. Berdasarkan uraian tersebut diusulkan hipotesis berikut:

$\mathrm{H}_{1}$ : Current Ratio (CR) diduga berpengaruh negatif terhadap return saham

\subsection{Debt to Equity Ratio terhadap Return Saham}

Debt to equity ratio atau rasio utang terhadap ekuitas memperlihatkan perbandingan antara kewajiban dan ekuitas dalam pendanaan perusahaan, digambarkan dengan rumus sebagai berikut (Fahmi, 2012):

$$
D E R=\frac{\text { Total Debt }}{\text { Total Equity }}
$$

Debt to Equity Ratio yang tinggi berarti ketergantungan perusahaan terhadap utang semakin tinggi. Semakin tinggi kewajiban perusahaan terhadap pihak pembiayaan atau kreditur semakin besar biaya yang dikeluarkan untuk membayar margin atau bagi hasil sebagai keuntungan pihak lain. Laba yang diperoleh dari hasil usaha juga dialokasikan untuk membayar utang tersebut sehingga semakin berkurang dividen yang dapat dibagikan. Semakin sedikit dividen yang diperoleh investor, membuat investor cenderung tidak berminat berinvestasi di perusahaan yang memiliki DER yang tinggi. Penurunan minat investor tersebut berdampak negatif terhadap harga saham sehingga capital gain yang diharapkan juga tidak diperoleh (I'niswatin dkk., 2020). Hal tersebut didukung oleh hasil penelitian Choirurodin (2018) yang menyatakan bahwa DER berpengaruh negatif terhadap return saham. Berdasarkan uraian tersebut sebelumnya, maka dirumuskan hipotesis sebagai berikut:

$\mathrm{H}_{2}$ : Debt to Equity Ratio (DER) diduga berpengaruh negatif terhadap return saham

\subsection{Return on Equity terhadap Return Saham}

Return on equity atau hasil pengembalian atas ekuitas memperlihatkan sejauh manaperusahaan mengelola modal sendiri secara efektif. ROE juga digunakan untuk mengukur tingkat keuntungan dari investasi yang telah dilakukan pemilik modal sendiri atau pemegang saham perusahaan. Rasio ini mengkaji sejauh mana suatu perusahaan mempergunakan sumber daya yang dimiliki untuk mampu memberikan laba atas ekuitas. Adapun rumus return on equity dinyatakan dalam persentase, sebagai berikut (Fahmi, 2012):

$$
R O E=\frac{\text { Earning After Tax (EAT) }}{\text { Shareholders'Equity }} \times 100 \%
$$

Semakin tinggi hasil return on equity, semakin besar laba yang diperoleh perusahaan, menunjukkan kinerja perusahaan dalam keadaan bagus. Investor berminat investasi pada perusahaan yang kinerjanya bagus, bertumbuh, menghasilkan keuntungan. Semakin dominan minat perusahaan membeli saham suatu perusahaan daripada menjual saham, semakin tinggi harga saham, sehingga semakin besar return on equity semakin besar return saham. Teori tersebut didukung oleh hasil penelitian Choirurodin (2018) bahwa Return on Equity berpengaruh positif terhadap return saham. Berdasarkan uraian tersebut sebelumnya, maka dirumuskan hipotesis sebagai berikut: 
$\mathrm{H}_{3}$ : Return on Equity (ROE) diduga berpengaruh positif terhadap return saham

\subsection{Tingkat Inflasi terhadap Return Saham}

Tingkat inflasi menggambarkan kondisi perekonomian. Inflasi yang terlalu tinggi meningkatkan biaya operasional yang dikeluarkan perusahaan. Biaya yang meningkat akan menurunkan laba yang dapat dibagikan kepada investor, sedangkan investor lebih tertarik berinvestasi ke perusahaan yang lebih banyak menghasilkan keuntungan. Semakin sedikit peminat saham perusahaan maka harga saham akan menurun sehingga capital loss harus diderita investor. Ketika capital loss dan dividen yang dibagikan menurun berarti return saham tidak diperoleh atau perolehannya kecil. Teori tersebut didukung hasil penelitian yang dilakukan Kurniasari (2018) dan Made dan Gusti (2017) yang menyakan inflasi memiliki pengaruh negatif secara langsung terhadap return saham dan signifikan. Berdasarkan uraian tersebut sebelumnya, maka dirumuskan hipotesis sebagai berikut:

$\mathrm{H}_{4}$ : Tingkat inflasi diduga berpengaruh negatif terhadap return saham

\subsection{Current Ratio, Debt to Equity Ratio, Return on Equity, dan Tingkat Inflasi terhadap Return Saham}

Faktor internal dan eksternal perusahaan merupakan dasar yang digunakan para investor untuk mengelola kegiatan investasinya. Ketika faktor internal dan eksternal secara bersama-sama ketika dianggap baik, maka semakin tinggi kepercayaan investor untuk melakukan investasi. Current ratio, debt to equity ratio, return on equity, dan tingkat inflasi merupakan faktor internal dan eksternal perusahaan. Menurut hasil penelitian Mayfi dan Rianto (2018) faktor internal dan eksternal perusahaan berpengaruh signifikan terhadap return saham. Berdasarkan uraian tersebut sebelumnya, maka dirumuskan hipotesis sebagai berikut:

$\mathrm{H}_{5}$ : CR, DER, ROE, dan Tingkat Inflasi secara simultan diduga berpengaruh terhadap return saham

\section{Metode Penelitian}

\subsection{Metode Penelitian yang Digunakan}

Penelitian yang dilakukan penulis menggunakan metode penelitian deskriptif dengan pendekatan kuantitatif. Penelitian dengan pendekatan kuantitatif menekankan fenomenfenomena objektif dan dikaji secara kuantitatif, yaitu dengan menggunakan angka-angka, pengelohan statistik, struktur dan percobaan terkontrol. Penelitian deskriptif adalah suatu metode penelitian yang ditujukan untuk menggambarkan beberapa fenomena yang ada, baik berlangsung saat ini maupun saat lampau (Hamdi \& Bahruddin, 2014). Menurut Nazir dalam (Hamdi \& Bahruddin, 2014) tujuan penelitian deskriptif adalah membuat deskripsi, gambaran atau lukisan secara sistematis, faktual dan akurat mengenai fakta-fakta, sifat-sifat atau hubungan antar fenomena yang diselidiki.

\subsection{Populasi dan Sampel}

Populasi dalam penelitian ini adalah perusahaan sektor jasa syariah yang terdaftar di Indeks Saham Syariah Indonesia. Perusahaan jasa syariah yang termasuk ke Indeks Saham Syariah Indonesia sektor Trade, Service, and Investment tahun 2012 sampai dengan 2018. Populasi berjumlah 82 perusahaan. Sampel dalam penelitian ini diambil dengan cara purposive sampling. Kriteria yang digunakan untuk menentukan sampel dalam 
penelitian ini adalah:

a. Perusahaan sektor trade, service, and retail sub sektor tourism, restaurant, and hotel yang listing di Indeks Saham Syariah Indonesia periode 2012-2018.

b. Perusahaan syariah sub sektor tourism, restaurant, and hotel yang tidak mengalami delisting maupun relisting selama periode 2012-2018

c. Tersedia laporan keuangan dan/ atau ringkasan performa perusahaan tahun 20122018.

Berdasarkan kriteria tersebut diperoleh sampel dalam penelitian ini empat belas perusahaan sub sektor tourism, restaurant, and hotel yang terdaftar di Indeks Saham Syariah Indonesia tahun 2012-2018.

\section{Hasil dan Pembahasan}

\subsection{Pemilihan Model}

Terdapat tiga model regresi data panel, yaitu commond effect model, fixed effect model, dan random effect model. Uji Chow dilakukan untuk memilih commond effect model atau fixed effect model, berikut ini hasil uji chow:

Tabel 3 Uji Chow

\begin{tabular}{lcrc}
\hline Redundant Fixed Effects Tests & & & \\
\hline Equation: Untitled & & & \\
\hline Test cross-section fixed effects & & & \\
\hline Effects Test & Statistic & d.f. & Prob. \\
\hline Cross-section F & 0.920975 & $(13,80)$ & 0.5355 \\
\hline Cross-section Chi-square & 13.667562 & 13 & 0.3977
\end{tabular}

Probabilitas chi-square sebesar $0.3977>0.05$, maka keputusan yang diambil adalah memilih Common Effect Model.

Commond effect model dan random effect model dipilih menggunakan uji lagrange multiplier, berikut ini hasil uji lagrange multiplier:

Tabel 4 Uji Lagrange Multiplier

\begin{tabular}{|c|c|c|c|}
\hline \multicolumn{4}{|c|}{ Lagrange multiplier (LM) test for panel data } \\
\hline \multicolumn{4}{|c|}{ Date: $05 / 27 / 20$ Time: $10: 05$} \\
\hline \multicolumn{4}{|c|}{ Sample: 20122018} \\
\hline \multicolumn{4}{|c|}{ Total panel observations: 98} \\
\hline \multicolumn{4}{|l|}{ Probability in 0} \\
\hline \multicolumn{4}{|l|}{ Null (no rand. } \\
\hline Alternative & One-sided & One-sided & \\
\hline \multirow[t]{2}{*}{ Breusch-Pagan } & 0.329384 & 2.678730 & 3.008114 \\
\hline & $(0.5660)$ & $(0.1017)$ & $(0.0828)$ \\
\hline \multirow[t]{2}{*}{ Honda } & -0.573920 & -1.636683 & -1.563132 \\
\hline & $(0.7170)$ & $(0.9492)$ & $(0.9410)$ \\
\hline \multirow[t]{2}{*}{ King-Wu } & -0.573920 & -1.636683 & -1.676330 \\
\hline & $(0.7170)$ & $(0.9492)$ & $(0.9532)$ \\
\hline \multirow[t]{2}{*}{ GHM } & -- & -- & 0.000000 \\
\hline & -- & -- & $(0.7500)$ \\
\hline
\end{tabular}


Probabilitas Breusch-Pagan (BP) sebesar 0,0828 > 0,05, maka memilih Common Effect Model. Common Effect Model menjadi model analisis terbaik yang dapat digunakan pada penelitian return saham sub sektor tourism, restaurant, and hotel yang terdaftar di ISSI periode 2012-2018.

Jika model yang terpilih ialah common effect atau fixed effect maka uji asumsi klasik yang harus dilakukan meliputi uji heteroskedastisitas dan uji multikolinieritas (Sakti, 2018). Berikut ini hasil uji asumsi klasik penelitian:

Tabel 5 Uji Heteroskedastisitas

\begin{tabular}{llll}
\hline \multicolumn{4}{l}{ Heteroskedasticity Test: ARCH } \\
\hline F-statistic & 0.337016 & Prob. F(1,95) & 0.5629 \\
\hline Obs*R-squared & 0.342895 & Prob. Chi-Square(1) & 0.5582 \\
\hline
\end{tabular}

Uji heteroskedastisitas dapat dilakukan menggunakan ARCH. Pada ARCH digunakan resid^2 disertai nilai lag (Winarno, 2017). Nilai Probabilitas $>0.05$, maka tidak terjadi heteroskedastisitas, artinya tidak ada nilai residual yang ekstrim.

Berikut ini tabel yang menunjukkan uji multikolinieritas regresi data panel model common effect model:

Tabel 6 Uji Multikolinieritas

\begin{tabular}{ccccc}
\hline & CR & DER & ROE & INFLASI \\
\hline CR & 1.000000 & -0.199055 & -0.024689 & -0.087747 \\
\hline DER & -0.199055 & 1.000000 & 0.144207 & -0.069503 \\
\hline ROE & -0.024689 & 0.144207 & 1.000000 & 0.124192 \\
\hline INFLASI & -0.087747 & -0.069503 & 0.124192 & 1.000000 \\
\hline
\end{tabular}

Ketika nilai koefisien rendah, maka tidak terdapat multikolinieritas (Winarno, 2017). Korelasi antara variabel bebas tertinggi sebesar 0.199055, tidak ada yang lebih dari besar dari 0.9, maka tidak terjadi multikolinieritas, artinya tidak ada hubungan linier antarvariabel independen.

Model regresi data panel memenuhi uji asumsi klasik, yaitu tidak ada multikolinieritas dan tidak ada heteroskedastisitas. Common Effect Model sebagai model yang dipilih dapat digunakan untuk penelitian karena memenuhi asumsi klasik yang diperlukan, probabilitas $F$ hitung lebih kecil dari tingkat signifikansi 0.05, dan koefisien determinasi bernilai positif.

\subsection{Uji Hipotesis}

Berikut ini tabel regresi common effect model yang terpilih untuk dilakukan uji hipotesis: 
Tabel 7 Uji Hipotesis

\begin{tabular}{|c|c|c|c|c|}
\hline \multicolumn{5}{|c|}{ Dependent Variable: Return Saham } \\
\hline \multicolumn{5}{|c|}{ Method: Panel Least Squares } \\
\hline \multicolumn{5}{|c|}{ Date: $05 / 27 / 20$ Time: 09:47 } \\
\hline \multicolumn{5}{|l|}{ Sample: 20122018} \\
\hline \multicolumn{5}{|l|}{ Periods included: 7} \\
\hline \multicolumn{5}{|c|}{ Cross-sections included: 14} \\
\hline \multicolumn{5}{|c|}{ Total panel (balanced) observations: 98} \\
\hline Variable & Coefficient & Std. Error & t-Statistic & Prob. \\
\hline $\mathrm{C}$ & 0.139143 & 0.179225 & 0.776360 & 0.4395 \\
\hline CR & 0.059746 & 0.039061 & 1.529567 & 0.1295 \\
\hline DER & 0.028757 & 0.071816 & 0.400421 & 0.6898 \\
\hline ROE & -1.976620 & 0.654986 & -3.017807 & 0.0033 \\
\hline Inflasi & $3.91 \mathrm{E}-06$ & $2.22 \mathrm{E}-05$ & 0.175837 & 0.8608 \\
\hline R-squared & 0.110566 & \multicolumn{2}{|c|}{ Mean dependent var } & 0.172930 \\
\hline Adjusted R-squared & 0.072311 & \multicolumn{2}{|c|}{ S.D. dependent var } & 0.586317 \\
\hline S.E. of regression & 0.564720 & \multicolumn{2}{|c|}{ Akaike info criterion } & 1.744701 \\
\hline Sum squared resid & 29.65855 & \multicolumn{2}{|c|}{ Schwarz criterion } & 1.876587 \\
\hline Log likelihood & -80.49034 & \multicolumn{2}{|c|}{ Hannan-Quinn criter. } & 1.798046 \\
\hline F-statistic & 2.890216 & \multicolumn{2}{|c|}{ Durbin-Watson stat } & 1.632805 \\
\hline Prob(F-statistic) & 0.026427 & & & \\
\hline
\end{tabular}

\subsubsection{Uji Parsial (Uji t)}

Memperhatikan Memperhatikan tabel uji hipotesis diperoleh hasil uji parsial sebagai berikut:

a. Variabel CR terhadap Return Saham

Nilai koefisien CR bernilai positif sebesar 0.059746. Besarnya t-statistic CR sebesar $1.529567<$ t-tabel sebesar 1.66140, dengan probabilitas t-statistic $\mathrm{CR}$ sebesar $0.1295>$ taraf signifikansi sebesar 0.05, maka $\mathrm{H}_{0}$ diterima dan $\mathrm{H}_{\mathrm{a}}$ ditolak. Current Ratio (CR) tidak berpengaruh signifikan terhadap Return Saham.

\section{b. Variabel DER terhadap Return Saham}

Nilai koefisien DER bernilai positif sebesar 0.028757. Besar t-statistic DER sebesar $0.400421<$ t-tabel sebesar 1.66140, dengan probabilitas tstatistic DER sebesar $0.6898>$ taraf signifikansi sebesar 0.05 , maka $\mathrm{H}_{0}$ diterima dan $\mathrm{H}_{a}$ ditolak. Tidak ada pengaruh signifikan antara Debt to Equity Ratio (DER) terhadap Return Saham.

c. Variabel ROE terhadap Return Saham

Nilai koefisien ROE bernilai negatif sebesar 1.976620. Besar t-statistic ROE sebesar $-3.017807>$ t-tabel sebesar 1.66140, dengan probabilitas tstatistic ROE sebesar $0.0033<$ taraf signifikansi sebesar 0.05, maka $\mathrm{H}_{a}$ diterima dan $\mathrm{H}_{0}$ ditolak. Terdapat pengaruh signifikan variabel Return on Equity (ROE) terhadap Return Saham. Ketika ROE meningkat sebesar 1 maka return 
saham akan menurun sebesar 1.976620.

d. Variabel Tingkat Inflasi terhadap Return Saham

Nilai koefisien Inflasi bernilai positif sebesar 0.390887. Besar t-statistic tingkat inflasi sebesar $0.175837<\mathrm{t}$-tabel sebesar 1.66140, dengan probabilitas t-statistic tingkat inflasi sebesar $0.8608>$ taraf signifikansi sebesar 0.05, maka $\mathrm{H}_{0}$ diterima dan $\mathrm{H}_{\mathrm{a}}$ ditolak. Tingkat Inflasi tidak berpengaruh signifikan terhadap Return Saham.

\subsubsection{Uji Simultan (Uji F)}

Penelitian ini menunjukkan F-statistic sebesar 2.890216 $>\mathrm{F}_{\text {tabel }}$ sebesar 2.47 dengan probabilitas F-statistic sebesar $0.026427<0.05$, maka $\mathrm{H}_{0}$ ditolak dan $\mathrm{H}_{a}$ diterima. Current ratio, debt to equity ratio, return on equity, dan tingkat inflasi secara simultan berpengaruh signifikan terhadap return saham. Ketika variabel bebas bernilai nol, maka nilai return saham sebesar 0.139143 .

\subsubsection{Koefisien Determinasi (R-square)}

Koefisien Determinasi ( $\mathrm{R}$ square), dilakukan untuk mengetahui besarnya variable-variabel independen yang diteliti dalam mempengaruhi variable dependen. Besarnya nilai $\mathrm{R}^{2}$ berada di antara 0 (nol) dan 1 (satu) yaitu $0<\mathrm{R}^{2}<$ 1. Jika $\mathrm{R}^{2}$ semakin mendekati 1 (satu), maka model tersebut baik dan pengaruh antara variabel terkait $\mathrm{Y}$ semakin kuat (erat hubungannya). Berdasarkan tabel IV.13, besarnya $\mathrm{R}$ square adalah 0.110566 atau $11.0566 \%$ dan $\mathrm{R}$ square adjusted sebesar $7.2311 \%$. Besarnya variabel current ratio, debt to equity ratio, return on equity, dan tingkat inflasi dalam mempengaruhi return saham adalah $7.23 \%$, sedangkan $92.77 \%$ sisanya dipengaruhi oleh faktor-faktor lain.

\subsection{Pembahasan}

\subsubsection{Pengaruh current ratio terhadap return saham}

Hasil penelitian menunjukkan bahwa current ratio tidak berpengaruh signifikan terhadap return saham perusahaan sub sektor tourism, restaurant, and hotel yang terdaftar di ISSI. Hal ini tidak sejalan dengan hipotesis satu $\left(\mathrm{H}_{1}\right)$ yang menyatakan terdapat pengaruh negatif current ratio terhadap return saham, maka $\mathrm{H}_{1}$ ditolak. Penelitian ini sejalan dengan penelitian Tumonggor (2017) yang menyatakan tidak terdapat pengaruh signifikan current ratio terhadap return saham.

Current ratio yang rendah menggambarkan adanya masalah likuiditas, namun ketika terlalu tinggi menunjukkan bahwa perusahaan kurang mampu mengelola uang dalam hal menghasilkan keuntungan yang akhirnya mengurangi kemampuan perusahaan memperoleh keuntungan (Amrin, 2009). Proporsi current ratio yang tinggi tidak selalu menggambarkan kemampuan perusahaan membayar utang lancarnya lebih mudah, karena aktiva lancar yang dinilai menggunakan current ratio memiliki likuiditas yang berbeda seperti piutang yang terlalu besar dengan jatuh tempo yang masih lama, maka tidak dapat dicairkan segera. Berdasarkan paparan tersebut, maka current ratio bukan faktor utama yang mempengaruhi return saham perusahaan. 


\subsubsection{Pengaruh debt to equity ratio terhadap return saham}

Tidak terdapat pengaruh signifikan antara DER terhadap return saham perusahaan sub sektor tourism, restaurant, and hotel yang terdaftar di ISSI periode 2012-2018. Hasil penelitian ini tidak sejalan dengan hipotesis dua $\left(\mathrm{H}_{2}\right)$ yang menyatakan DER berpengaruh negatif terhadap return saham. Penelitian ini sejalan dengan penelitian Tumonggor (2017), Sugiarti (2015), Fathimah (2018) yang menyatakan bahwa DER tidak berpengaruh terhadap return saham.

Besar debt to equity ratio menunjukkan perbandingan antara utang dengan ekuitas. Semakin besar utang perusahaan yang dikelola dengan baik dapat meningkatkan keuntungan perusahaan, namun jika tidak dikelola dengan baik, maka tidak sebanding dengan biaya pengorbanan untuk membayar fee atau bagi hasil atas perolehan utang atau pembiayaan. Pengelolaan yang baik dan tidak baik tersebut tidak dapat dilihat dari besar kecilnya DER, sehingga debt to equity ratio yang tinggi tidak selalu direspon positif oleh investor. Investor lebih tertarik pada hasil pengelolaan perusahaan dan bukan pada cara pengelolaannya (Samsul, 2006).

\subsubsection{Pengaruh return on equity terhadap return saham}

Terdapat pengaruh signifikan return on equity (ROE) terhadap return saham perusahaan sub sektor tourism, restaurant, and hotel yang terdaftar di ISSI. Pengaruh yang ditunjukkan berarah negatif, artinya peningkatan ROE akan mengakibatkan return saham menurun. Hal ini tidak sejalan dengan hipotesis tiga $\left(\mathrm{H}_{3}\right)$ yang menduga adanya pengaruh positif ROE terhadap return saham. Penelitian ini mendukung penelitian Aryanti dan Mawardi (2016) yang menyatakan secara parsial return on equity berpengaruh negatif signifikan terhadap return saham.

Teori pensignalan (signaling theory) mengungkapkan bahwa ROE berpengaruh positif terhadap return saham. Teori tersebut tidak didukung penelitian yang dilakukan pada perusahaan sub sektor tourism, restaurant, and hotel yang terdaftar di ISSI periode 2012-2018. Kondisi ini disebabkan pola distribusi data ROE cenderung menurun ketika return saham mengalami peningkatan. ROE merupakan perbandingan antara Earning After Tax (EAT) terhadap Equity, maka apabila total ekuitas perusahaan memang besar bisa timbul hasil negatif walaupun EAT yang dimiliki suatu perusahaan sebetulnya meningkat (Galuh \& Mai, 2020) Ekuitas perusahaan sub sektor tourism, restaurant, and hotel periode 2012-2018 cenderung meningkat setiap tahunnya. Diperlukan jeda waktu (time lag) pengaruh ROE terhadap return saham.

Return saham terbentuk dari selisih harga jual dengan harga beli saham. Harga saham bergerak karena persepsi fundamental, untuk mengetahui perusahaan yang bagus, namun setiap orang memiliki opini masing-masing. Apabila kumpulan investor dominan membeli saham, maka harga saham akan naik menghasilkan capital gain sehingga return saham positif, ketika investor dominan menjual saham, maka harga saham cenderung turun mengakibatkan capital loss sehingga return saham negatif. Investor dominan optimis ketika return on equity perusahaan sub sektor tourism, restaurant, and hotel menurun dengan tetap membeli saham, sehingga semakin kuat pembelian saham harga saham akan meningkat menghasilkan return saham berupa capital gain.

Ketika profitabilitas yang ditunjukkan oleh ROE tinggi, investor akan beropini bahwa harga sahamnya mahal, investor memilih saham lain yang harganya masih 
terjangkau. Disamping itu, investor yang telah memiliki saham dengan profitabilitas yang tinggi justru menjual saham tersebut karena harganya mahal. Banyaknya penawaran dibandingkan permintaan akan menurunkan harga saham sehingga return saham menurun. Pada kasus ini berlaku analisis teknikal.

\subsubsection{Pengaruh tingkat inflasi terhadap return saham}

Hasil pengujian menunjukkan bahwa tingkat inflasi tidak berpengaruh signifikan terhadap return saham perusahaan sub sektor tourism, restaurant, and hotel yang terdaftar di ISSI periode 2012-2018. Hal ini tidak sejalan dengan hipotesis sementara yang menyatakan terdapat pengaruh negatif tingkat inflasi terhadap return saham $\left(\mathrm{H}_{4}\right)$. Penelitian ini mendukung penelitian Afiyati dan Topowijono yang menyatakan bahwa inflasi tidak berpengaruh signifikan terhadap return saham.

Inflasi dapat menjadi indikator untuk melihat tingkat perubahan serta dianggap terjadi jika proses kenaikan harga berlangsung secara terus-menerus dan saling pengaruhmemengaruhi. (Tripuspitorini \& Setiwan, 2020). Tingkat inflasi yang meningkat menunjukkan peningkatan pertumbuhan ekonomi, termasuk kegiatan di pasar modal syariah, namun inflasi yang terlalu tinggi dapat mengakibatkan kebangkrutan suatu perusahaan karena harga-harga cenderung meningkat secara terus-menerus, biaya operasional meningkat sedangkan daya beli masyarakat menurun.

Tingkat inflasi yang terjadi pada periode penelitian cenderung menunjukkan tingkat inflasi yang baik. Tingkat inflasi yang baik adalah inflasi yang tidak melebihi besarnya pertumbuhan ekonomi. Pertumbuhan ekonomi Indonesia diukur berdasarkan Produk Domestik Bruto (PDB). Tingkat inflasi pada tahun 2012, 2015, 2016, 2017, dan 2018 menunjukkan tingkat inflasi yang baik, terjadi pertumbuhan perekonomian. Daya beli masyarakat menigkat sehingga return saham meningkat. Tingkat inflasi pada tahun 2013 dan 2014 menunjukkan melemahnya perekonomian sehingga pergerakan jual beli saham pun menurun, mengakibatkan return saham menurun.

Tingkat inflasi merupakan faktor eksternal perusahaan yang diduga mempengaruhi return saham, namun dalam penelitian ini, inflasi tidak memiliki pengaruh signifikan terhadap return saham, karena return saham dapat dipengaruhi kebijakan perusahaan dengan mengubah hal-hal fundamental perusahaan.

\subsubsection{Pengaruh current ratio, debt to equity ratio, return on equity, dan tingkat inflasi terhadap return saham}

Hasil penelitian menunjukkan bahwa current ratio, debt to equity ratio, return on equity, dan tingkat inflasi berpengaruh signifikan terhadap return saham perusahaan sub sektor tourism, restaurant, and hotel yang terdaftar di ISSI periode 2012-2018. Penelitian ini sejalan dengan hipotesis lima $\left(\mathrm{H}_{5}\right)$ yang menyatakan current ratio, debt to equity ratio, return on equity, dan tingkat inflasi berpengaruh signifikan terhadap return saham. Kontribusi variabel-variabel independen memiliki pengaruh yang rendah terhadap return saham, ditunjukkan dengan koefisien determinasi model regresi kurang dari $25 \%$.

\section{Penutup}

Current ratio, debt to equity ratio, dan tingkat inflasi secara parsial tidak berpengaruh signifikan terhadap return saham perusahaan sub sektor tourism, 
restaurant, and hotel yang terdafatar di Indeks Saham Syariah Indonesia, sedangkan return on equity secara parsial berpengaruh negatif signifikan terhadap return saham perusahaan sub sektor tourism, restaurant, and botel yang terdaftar di Indeks Saham Syariah Indonesia. Current ratio, debt to equity ratio, return on equity, dan tingkat inflasi secara simultan berpengaruh signifikan terhadap return saham perusahaan sub sektor tourism, restaurant, and botel yang terdafatar di Indeks Saham Syariah Indonesia.

\section{Daftar Pustaka}

Abdulmannan, A. A., \& Faturohman, T. (2015). Factors and Stock Return: A Case Based Approach on Banking Companies Listed in Indonesia Stock Exchange. Journal of Business and Management, 4, 579-586.

Afiyati, H. T., \& Topowijoyo. (2018). Pengaruh Inflasi, BI Rate dan Nilai Tukar terhadap Return Saham (Studi pada Perusahaan Subsector food \& beverages yang terdaftar di Bursa Efek Indonesia Periode2013-2016). Jurnal Administrasi Bisnis, 61, 144-151.

Amrin, A. (2009). Bisnis, Ekonomi, Asuransi, dan Keuangan Syariah. Grasindo.

Aryanti, Mawardi, \& Andesta, S. (2016). Pengaruh ROA, ROE, NPM, dan CR terhadap Return Saham pada Perusahaan yang Terdafar di Jakarta Islamic Index (JII). I-Finance, 2, 54-71.

Choirurodin. (2018). Pengaruh Current Ratio, Return on Equity, Debt to Equit Ratio terhadap Return Saham (Pada Perusahaan Food and Beverages yang Terdaftar di BEI Periode 20132016). Skripsi Program Sarjana Universitas Negeri Yogyakarta.

Fahmi, I. (2012). Pengantar Pasar Modal. Allfabeta.

Farihah, S. M., \& Setiawan, S. (2020). Determinan Intellectual Capital terbadap Profitabilitas di Bank Syariah: Pengujian Mediasi Kinerja Keuangan dan Kinerja Non Kenangan Determinant of Intellectual Capital on Profitability in Islamic Banks: Testing Mediation of Financial Performance and Non-Financial Performance. 11(28), 151-165. https://doi.org/10.33059/jseb.v11i2.1996

Galuh, N. R., \& Mai, M. U. (2020). Pengarub Corporate Sosial Responsibility Terbadap Syariah. 19(1), 6978.

Geriadi, M. A. D., \& Wiksuana, I. G. B. (2017). Pengaruh Inflasi terhadap Return Saham pada Perusahaan Property and Estate yang Terdaftar di Bursa Efek Indonesia (Risiko Sistematis dan Profitabilitas sebagai Variabel Mediasi). E-Jurnal Ekonomi Dan Bisnis Universitas Udayana, 6.9, 3435-3462.

Hamdi, A. S., \& Bahruddin, E. (2014). Metode Penelitian Kuantitatif Aplikasi dalam Pendidikan. Deepublish.

Hayati, S. (2017). Manajemen Risiko untuk Bank Perkreditan Rakyar dan Lembaga Kenangan Mikro. CV Andi Ofset.

I'niswatin, A., R Purbayati, S Setiawan. (2020). Pengaruh Debt to Equity Ratio dan Return on Equity terhadap Harga Saham pada Perusahaan Makanan dan Minuman yang Terdaftar di Bursa Efek Indonesia. Indonesian Journal of Economics and Management 1(1), 96-110

Kurnniasari, W., Wiranto, A., \& Yusuf, M. (2015). Pengaruh Inflasi dan Suku Bunga terhadap Return Saham dengan Profitabilitas sebagai Variabel Intervening di Perbankan yang Terdaftar di Bursa Efek Indonesia Tahun 2013-2015. Journal of Accounting, 2, 67-90.

Manurung, A. H. (2009). Kaya dari Bermain Saham. PT Kompas Media Nusantara.

Mayfi, F., \& Rianto, D. (2018). Analisis Pengaruh Faktor Internal dan Eksternal terhadap Return Saham. Jurnal MIX, 4, 348-362. 
Rista Bintara, \& Putri Renalita Sutra Tanjung. (2019). Analysis of Fundamental Factors on Stock

Return. Journal of Academic Research in Accounting, Finance, and Management Sciences, 9, 49-64.

Sakti, I. (2018). Analisis Regresi Data Panel Menggunakan Eviews. Universitas Esa Unggul.

Samsul, M. (2006). Manajemen Portofolio. Erlangga.

Sawir, A. (2009). Analisis Kinerja Kenangan dan Perencanaan Keuangan Perusabaan. PT Gramedia Pustaka Utama.

Sugiarti. (20015). Pengaruh Kinerja Perusahaan terhadap Return Saham (Studi pada Perusahaan Manufaktur yang Terdaftar di Bursa Efek Indonesia). Jurnall Aplikasi Manajemen, 13, 282-298.

Tripuspitorini, F. A. \& Setiawan, S. (2020). Pengarub Faktor Makroekonomi Terhadap Pertumbuban Dana Pihak Ketiga Pada Bank Umum Syariah di Indonesia. Jurnal Riset Akuntansi, 8(1), 121-132.

Tumonggor, M., Murni, S., \& Rate, P. Van. (2017). Analisis Pengaruh Current Ratio, Return on Equity, Debt to Equity Ratio, dan Growth terhadap Return Saham pada Cosmetics and Household Industry yang Terdaftar di BEI Periode 2010-2016. Jurnal EMBA, 5, 2203-2210.

Winarno, W. W. (2017). Analisis Ekonometrika dan Statistika dengan Eviews. In Edisi 5. STIM YKPN. 